\title{
Collagen regulates transforming growth factor- $\beta$ receptors of HL-1 cardiomyocytes through activation of stretch and integrin signaling
}

\author{
YEN-YU LU ${ }^{1,2}$, YUNG-KUO LIN ${ }^{3,4}$, YU-HSUN KAO ${ }^{5,6}$, CHENG-CHIH CHUNG ${ }^{4,5}$, \\ YUNG-HSIN YEH $^{7}$, SHIH-ANN CHEN ${ }^{8,9}$ and YI-JEN CHEN ${ }^{4,5}$
}

\begin{abstract}
${ }^{1}$ Division of Cardiology, Department of Internal Medicine, Sijhih Cathay General Hospital, New Taipei City 221; ${ }^{2}$ School of Medicine, Fu-Jen Catholic University, New Taipei City 242; ${ }^{3}$ Division of Cardiology, Department of Internal Medicine, School of Medicine, College of Medicine, Taipei Medical University, Taipei 110; ${ }^{4}$ Division of Cardiovascular Medicine, Department of Internal Medicine, Wan Fang Hospital, Taipei Medical University, Taipei $116 ;{ }^{5}$ Graduate Institute of Clinical Medicine, College of Medicine, Taipei Medical University, Taipei 110; ${ }^{6}$ Department of Medical Education and Research, Wan Fang Hospital, Taipei Medical University, Taipei 116; ${ }^{7}$ Cardiovascular Division, Chang Gung Memorial Hospital, Chang Gung University College of Medicine, Tao-Yuan 333; ${ }^{8}$ School of Medicine, National Yang-Ming University, Taipei 112; ${ }^{9}$ Division of Cardiology and Cardiovascular Research Center, Veterans General Hospital-Taipei, Taipei 116, Taiwan, R.O.C.
\end{abstract}

Received August 8,2015; Accepted July 13, 2016

DOI: $10.3892 / \mathrm{mmr} .2016 .5635$

\begin{abstract}
The extracellular matrix (ECM) and transforming growth factor- $\beta$ (TGF)- $\beta$ are important in cardiac fibrosis, however, the effects of the ECM on TGF- $\beta$ signaling remain to be fully elucidated. The aims of the present study were to evaluate the role of collagen in TGF- $\beta$ signaling and examine the underlying mechanisms. In the present study, western blot analysis was used to examine TGF- $\beta$ signaling in HL-1 cells treated with and without (control) type I collagen $(10 \mu \mathrm{g} / \mathrm{ml})$, which was co-administered with either an anti- $\beta 1$ integrin antibody $(10 \mu \mathrm{g} / \mathrm{ml})$ or a stretch-activated channel inhibitor (gadolinium; $50 \mu \mathrm{M}$ ). Cell proliferation and adhesion assays were used to investigate the roles of integrin, mechanical stretch and mitogen-activated protein kinases (MAPKs) on cell proliferation and adhesion. The type I collagen $(10 \mu \mathrm{g} / \mathrm{ml})$-treated HL-1 cells were incubated with or without anti- $\beta 1$ integrin antibody $(10 \mu \mathrm{g} / \mathrm{ml})$, gadolinium $(50 \mu \mathrm{M})$ or inhibitors of $\mathrm{p} 38(\mathrm{SB} 203580 ; 3 \mu \mathrm{M})$, extracellular signal-regulated kinase (ERK; PD98059; $50 \mu \mathrm{M})$ and c-Jun $\mathrm{N}$-terminal kinase (JNK; SP600125; $50 \mu \mathrm{M}$ ). Compared
\end{abstract}

Correspondence to: Dr Yi-Jen Chen or Dr Yung-Kuo Lin, Division of Cardiovascular Medicine, Department of Internal Medicine, Wan Fang Hospital, Taipei Medical University, 111 Hsin-Lung Road, Sec. 3, Taipei 116, Taiwan, R.O.C.

E-mail: yjchen@tmu.edu.tw

E-mail: yklin213@yahoo.com.tw

Key words: collagen, integrin, mechanical stretch, mitogen-activated protein kinases, transforming growth factor- $\beta$ with the control cells, the collagen-treated HL-1 cells had lower expression levels of type I and type II TGF- $\beta$ receptors (TGF $\beta$ RI and TGF $\beta$ RII), with an increase in phosphorylated focal adhesion kinase (FAK), p38 and ERK1/2, and a decrease in JNK. Incubation with the anti- $\beta 1$ integrin antibody reversed the collagen-induced downregulation of the expression of TGF $\beta$ RII and phosphorylated FAK. Gadolinium downregulated the expression levels of TGF/RI and small mothers against decapentaplegic (Smad)2/3, and decreased the levels of phosphorylated p38, ERK1/2 and JNK. In addition, gadolinium reversed the collagen-induced activation of p38 and ERK1/2. In the presence of gadolinium and anti- $\beta 1$ integrin antibody, collagen regulated the expression levels of TGF $\beta$ RI, TGF $\beta$ RII and Smad2/3, but did not alter the phosphorylation of p38, ERK1/2 or JNK. In addition, collagen increased cell proliferation and adhesion, and this collagen-induced cell proliferation was inhibited by the anti- $\beta 1$ integrin antibody and ERK inhibitor. Taken together, the data obtained suggested that collagen differentially regulated the expression levels of TGF $\beta$ RI and TGF $\beta$ RII, and modulated the phosphorylation of MAPKs through integrin- or stretch-dependent and -independent signaling pathways.

\section{Introduction}

Cardiac fibrosis, as a consequence of remodeling processes, results from cardiac adaptations to the hemodynamic overload caused by heart failure and cardiac hypertrophy. Adaptive remodeling processes initiate structural alterations representing cell morphological changes and excessive deposition of extracellular matrix (ECM) (1-3). Substances in the ECM provide cardiomyocytes with structural, chemical and mechanical substrates, which are essential for normal development and 
responses to pathological signals. Cardiomyocytes can sense stimuli from the ECM, which results in structural or functional remodeling (4). Collagen, particularly type I, is a major component of the ECM, which forms networks in interstitial spaces among cells, and provides structural integrity and mechanical stretching of the heart (5). Therefore, type I collagen may be critical in cardiac fibrosis.

Transforming growth factor (TGF)- $\beta$ is a key mediator in the pathogenesis of hypertrophic and dilative ventricular remodeling by stimulating cardiomyocyte growth and inducing interstitial fibrosis $(6,7)$. In the pressure-overloaded human heart, the upregulation of TGF- $\beta$ is correlated with the degree of fibrosis (8). The overexpression of TGF- $\beta$ in transgenic mice has been found to result in atrial hypertrophy, which is characterized by interstitial fibrosis and hypertrophic growth of cardiomyocytes (9). Active TGF- $\beta$ binds to the constitutively active type II receptor (TGF $\beta$ RII) at the cell surface, and subsequently transphosphorylates the cytoplasmic domain of the type I receptor (TGF $\beta R I$ ) (10). As TGF $\beta$ RI mediates the majority of the cellular responses to TGF- $\beta_{1}$ and has a predominant role in intracellular signal transduction (11), the activation of TGF- $\beta$ receptors propagates downstream intracellular signals through Smad proteins, which are essential components in the signaling pathway of TGF- $\beta$ (10,12-14). Although TGF- $\beta$ signaling is important in genes associated with the ECM, whether the ECM is involved in regulating TGF- $\beta$ signaling remains to be elucidated.

In vivo, cardiomyocytes are intricately connected to the ECM, and stretch is transduced via the intercellular and ECM connections via proteins located on the cell surface and subcellular adhesion complexes, and via stretch-sensing proteins. Stretching and the expression of integrin are increased during cardiac fibrosis (15-17). Integrin represents a primary link between ECM ligands and directly initiates intracellular signaling cascades (18-21). Integrin can interact with TGF- $\beta$ to enhance cardiac fibrosis (21), suggesting that collagen may be involved in TGF- $\beta$ signaling, which regulates the homeostasis of cardiac fibrosis. Integrin can activate focal adhesion kinase (FAK), which results in cardiac structural and electrical changes (22). In addition, mechanical stretch is important in tissue morphogenesis and remodeling, and evokes various hypertrophic responses from cell adhesion receptors and the expression of TGF- $\beta_{1}$, and activates mitogen-activated protein kinases (MAPKs) in cardiomyocytes (23-25). Accordingly, integrin and mechanosensitive stretch channels may potentially regulate TGF- $\beta$ signaling. MAPKs have pathophysiological effects in cardiac remodeling (26). Our previous studies demonstrated that collagen can modulate calcium dynamics and electrical activities of cardiomyocytes, with activation of the renin-angiotensin and MAPK systems $(27,28)$. Therefore, the aims of the present study were to evaluate the effects of collagen on TGF- $\beta$ signaling and investigate the underlying mechanisms. The results of the present study demonstrated that collagen differentially modulated the expression levels of TGF $\beta$ RI and TGF $\beta$ RII and the activity of MAPKs through interactions of integrin with stretch signaling.

\section{Materials and methods}

Cell culture. The protocol was approved by the Department of Medical Research of Cathay General Hospital, Taipei, Taiwan (no. CGH-MR-10014). HL-1 cells derived from mouse atrial cardiac muscle cells (29) were provided by Dr Claycomb, Louisiana State University Health Sciences Center (New Orleans, USA). The cells for various experiments were cultured in a humidified atmosphere of $5 \% \mathrm{CO}_{2}$ at $37^{\circ} \mathrm{C}$ in Claycomb medium (JRH Biosciences, Lenexa, KS, USA). As described previously, the HL-1 cells were cultured with or without (control) type I rat tail tendon collagen $(10 \mu \mathrm{g} / \mathrm{ml}$; Sigma-Aldrich, St. Louis, MO, USA) for $24 \mathrm{~h}$ following cell seeding (27). To investigate the roles of integrin and stretch, the HL-1 cells were pretreated with either monoclonal hamster anti-rat $\beta 1$ integrin antibody ( $\beta 1$ integrin; $10 \mu \mathrm{g} / \mathrm{ml}$; clone Ha2/5; \#555002; BD Pharmingen, San Diego, CA, USA), to inhibit the in vitro adhesion of CD29-expressing cells to type I collagen, or the stretch-activated ion channel inhibitor, gadolinium (50 $\mu \mathrm{M}$; Sigma-Aldrich) for $30 \mathrm{~min}$ prior to collagen incubation $(30,31)$. The cells were plated at a density of $5 \times 10^{5}$ cells/well in 6-well culture plates.

Western blot analysis. The HL-1 cells were homogenized and lysed in RIPA buffer containing $50 \mathrm{mM}$ Tris ( $\mathrm{pH} 7.4)$, $150 \mathrm{mM} \mathrm{NaCl}, 1 \% \mathrm{NP} 40,0.5 \%$ sodium deoxycholate, $0.1 \%$ sodium dodecylsulfate (SDS) and protease inhibitor cocktails (Sigma-Aldrich). The protein concentrations were determined using Bio-Rad protein assay reagent (Bio-Rad Laboratories, Inc., Hercules, CA, USA). Protein samples $(40 \mu \mathrm{g})$ were separated by $10 \%$ SDS-polyacrylamide gel electrophoresis under reducing conditions and electrophoretically transferred onto equilibrated polyvinylidenedifluoride membranes (Amersham Biosciences, Upsulla, Sweden). The blots were probed with the following primary antibodies overnight at $4^{\circ} \mathrm{C}$ : Rabbit anti-FAK (cat. no. 3285; 1:1,000), rabbit anti-phosphorylated FAK (cat. no. 3283; 1:1,000), rabbit anti-extracellular signal-regulated kinase 1/2 (ERK1/2; cat. no. 9102; 1:1,000), rabbit anti-phosphorylated-ERK1/2 (cat. no. 4370; 1:1,000) rabbit anti-c-Jun N-terminal kinase (JNK; cat. no. 9258; 1:1,000), mouse anti-phosphorylated-JNK (cat. no. 9255; 1:1,000), rabbit anti-p38 (cat. no. 9212; 1:1,000), rabbit anti-phosphorylated-p38 (cat. no. 9211; 1:1,000), rabbit anti-Smad2/3 (cat. no. 8685; 1:1,000), rabbit anti-phosphorylated-Smad2/3 (cat. no. 8828; $1: 1,000$ ), rabbit anti-TGF $\beta$ RII (cat. no. 11888; 1:500) (all Cell Signaling Technology, Inc., Danvers, MA, USA); rabbit anti-TGFßRI (cat. no. SAB1300113, Sigma-Aldrich; 1:500); and horseradish peroxidase-conjugated goat anti-rabbit (cat. no. AP132P; 1:20,000) or goat anti-mouse immunglobulin G (cat. no. AP124P; 1:8,000) secondary antibodies (EMD Millipore, Billerica, MA, USA) for $1 \mathrm{~h}$ at room temperature. The bound antibodies were detected with an enhanced chemiluminescence detection system (EMD Millipore) and analyzed with AlphaEaseFC version 4.0 software (Alpha Innotech Corporation, San Leandro, CA, USA). The targeted bands were normalized to mouse anti-cardiac $\alpha$-sarcomeric actin (cat. no. A2172; Sigma-Aldrich; 1:2,000) to confirm equal protein loading.

Cell proliferation assay. Cell proliferation was analyzed using a BrdU incorporation assay (BrdU Cell Proliferation Assay kit, Cell Signaling Technologies, Inc.). The HL-1 cells were seeded at $1 \times 10^{4}$ cells/well in 96-well plates and left to attach overnight. The cells were then incubated with or without 
A
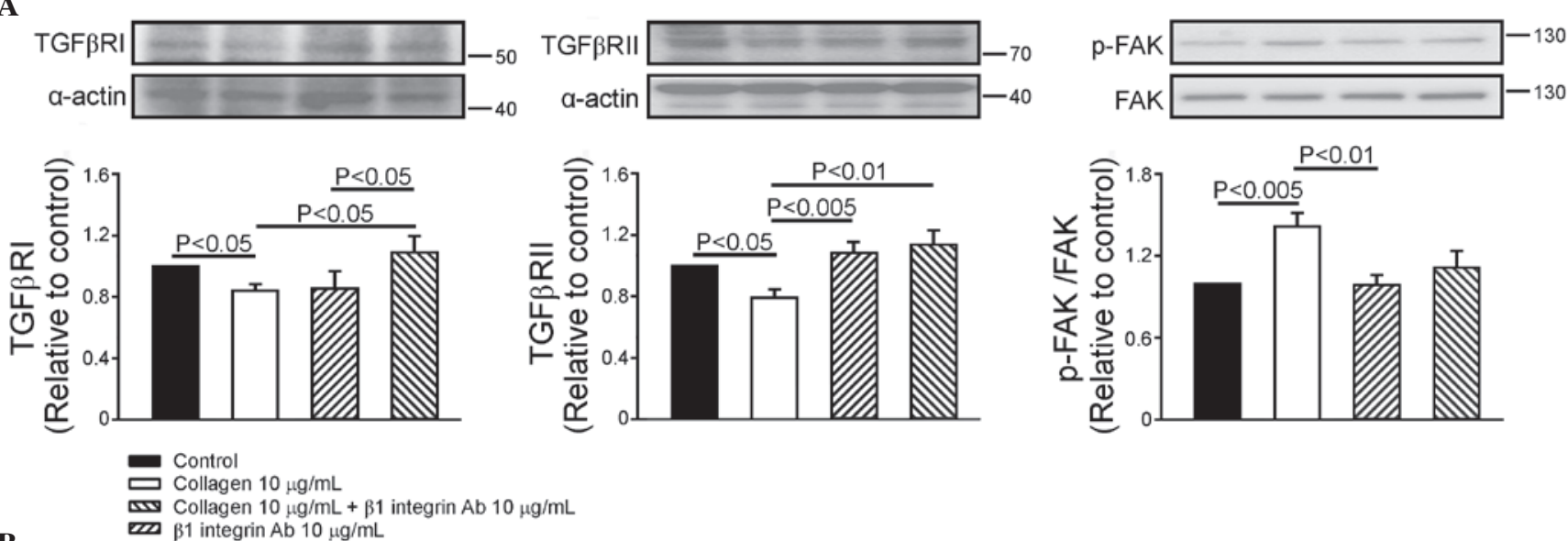

B
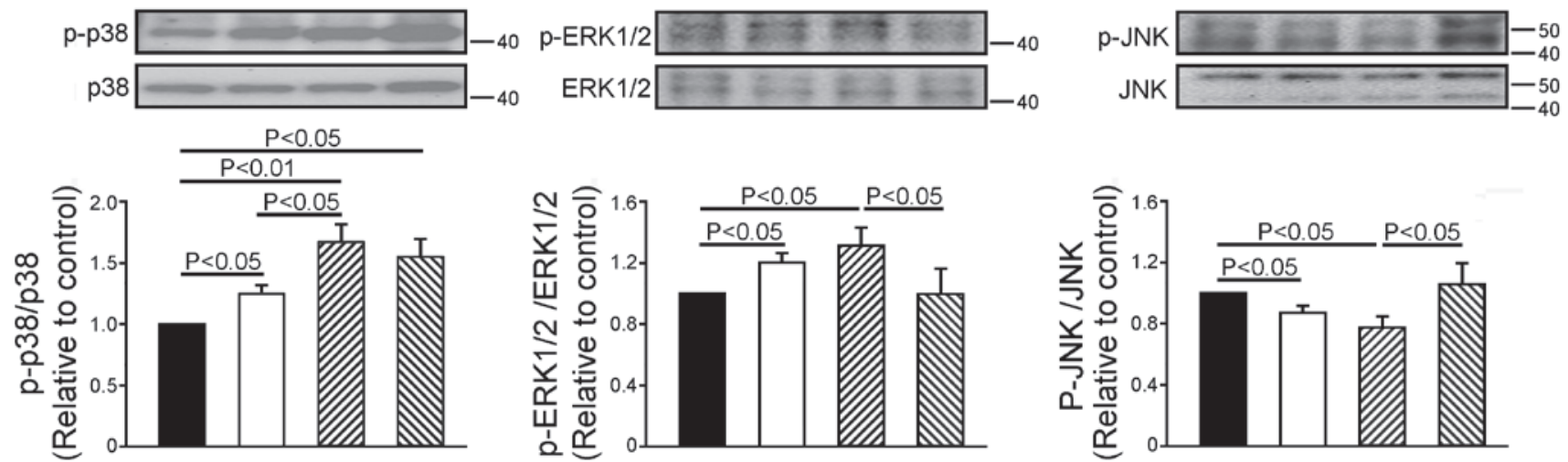

Figure 1. Effects of collagen and $\beta 1$ integrin Ab on the expression levels of TGF $\beta R I$ and TGF $\beta R I$, and the downstream signaling in HL- 1 cells. (A) Representative images and quantified data $(\mathrm{n}=7)$ of the expression levels of TGF $\beta$ RI and TGF $\beta$ RII, and the phosphorylation ratio of FAK in the control, collagen ( $10 \mu \mathrm{g} / \mathrm{ml})$-treated, collagen $(10 \mu \mathrm{g} / \mathrm{ml})$ with $\beta 1$ integrin $\mathrm{Ab}(10 \mu \mathrm{g} / \mathrm{ml})$-treated, and $\beta 1$ integrin $\mathrm{Ab}(10 \mu \mathrm{g} / \mathrm{ml})$-treated groups. (B) Representative image and quantified data $(\mathrm{n}=6)$ of the phosphorylation ratio of $\mathrm{p} 38$, ERK1/2 and JNK in the control, collagen $(10 \mu \mathrm{g} / \mathrm{ml})$-treated, collagen $(10 \mu \mathrm{g} / \mathrm{ml})$ with $\beta 1$ integrin Ab (10 $\mu \mathrm{g} / \mathrm{ml})$-treated and $\beta 1$ integrin $\mathrm{Ab}(10 \mu \mathrm{g} / \mathrm{ml})$-treated groups. Data are presented as the mean \pm standard error of the mean. TGF $\beta \mathrm{R}$, transforming growth factor $\beta$ receptor; FAK, focal adhesion kinase; ERK1/2, extracellular-regulated kinase 1/2; JNK, Jun N-terminal kinase; Ab, antibody; p-, phosphorylated.

type I rat tail tendon collagen $(10 \mu \mathrm{g} / \mathrm{ml})$ for $24 \mathrm{~h}$. The HL-1 cells were pretreated with $\beta 1$ integrin antibody $(10 \mu \mathrm{g} / \mathrm{ml})$, gadolinium $(50 \mu \mathrm{M})$, p38 MAPK inhibitor (SB203580; $3 \mu \mathrm{M}$; Merck Millipore, Darmstadt, Germany), ERK inhibitor (PD98059; $50 \mu \mathrm{M}$; Sigma-Aldrich) or JNK inhibitor (SP600125; $50 \mu \mathrm{M}$; Calbiochem, San Diego, CA, USA) for 30 min prior to collagen incubation. BrdU solution was added $4 \mathrm{~h}$ prior to the end of cell treatment. Following fixing of cells and denaturing of DNA, BrdU detection antibody and horseradish peroxidase-conjugated secondary antibody were added. Finally, the HRP substrate, 3,3',5,5'-tetramethylbenzidine, was added to develop color, and BrdU incorporation was quantified by reading the absorbance at $540 \mathrm{~nm}$.

Cell adhesion assay. The HL-1 cells were trypsinized and seeded at a density of $2 \times 10^{4}$ cells/well in a 96 -well plate following treatment with type I collagen $(10 \mu \mathrm{g} / \mathrm{ml})$ and $\beta 1$ integrin antibody $(10 \mu \mathrm{g} / \mathrm{ml})$. Subsequent to attachment for $2.5 \mathrm{~h}$ in a $37^{\circ} \mathrm{C}$ incubator, the unattached cells were removed by washing with phosphate-buffered saline. The cells were then stained with $0.1 \%$ crystal violet in $2 \%$ ethanol in $0.1 \mathrm{M}$ borate $(\mathrm{pH} \mathrm{9)}$ for $15 \mathrm{~min}$. Cell adhesion levels were evaluated by reading the absorbance of crystal violet at $540 \mathrm{~nm}$ following the addition of $100 \mathrm{ml}$ pure methanol to solubilize the dye.
Statistical analysis. Continuous variables are expressed as the mean \pm standard error of the mean. The different groups of HL-1 cells were compared using a paired $t$-test or repeated one-way analysis of variance with a Tukey's post-hoc test. The effects of the $\beta 1$ integrin antibody or gadolinium on collagen were evaluated using an unpaired $t$-test. All statistical tests were performed using SigmaStat 3.5 (Systat Software, Inc., San Jose, CA, USA). P $<0.05$ was considered to indicate a statistically significant difference.

\section{Results}

Effects of collagen and $\beta 1$ integrin in modulating the expression of TGF- $\beta$ receptors and FAK. Compared with the control, the collagen $(10 \mu \mathrm{g} / \mathrm{ml})$-treated HL-1 cells exhibited significantly decreased expression levels of TGF $\beta$ RI $(16 \pm 5 \%)$ and TGF $\beta$ RII $(21 \pm 5 \%)$ and upregulated FAK phosphorylation, (42 $\pm 9 \%)$. The $\beta 1$ integrin antibody $(10 \mu \mathrm{g} / \mathrm{ml})$ did not alter the expression levels of TGF $\beta$ RI, TGF $\beta$ RII or the phosphorylation of FAK in the HL- 1 cells. In the presence of the $\beta 1$ integrin antibody, collagen downregulated the expression of TGF $\beta$ RI, however, no effects on the expression of TGF $\beta$ RII or the phosphorylation of FAK were observed (Fig. 1A). Therefore, the $\beta 1$ integrin antibody attenuated the collagen-associated downregulation in the expression of TGF $\beta$ RII and phosphorylation 


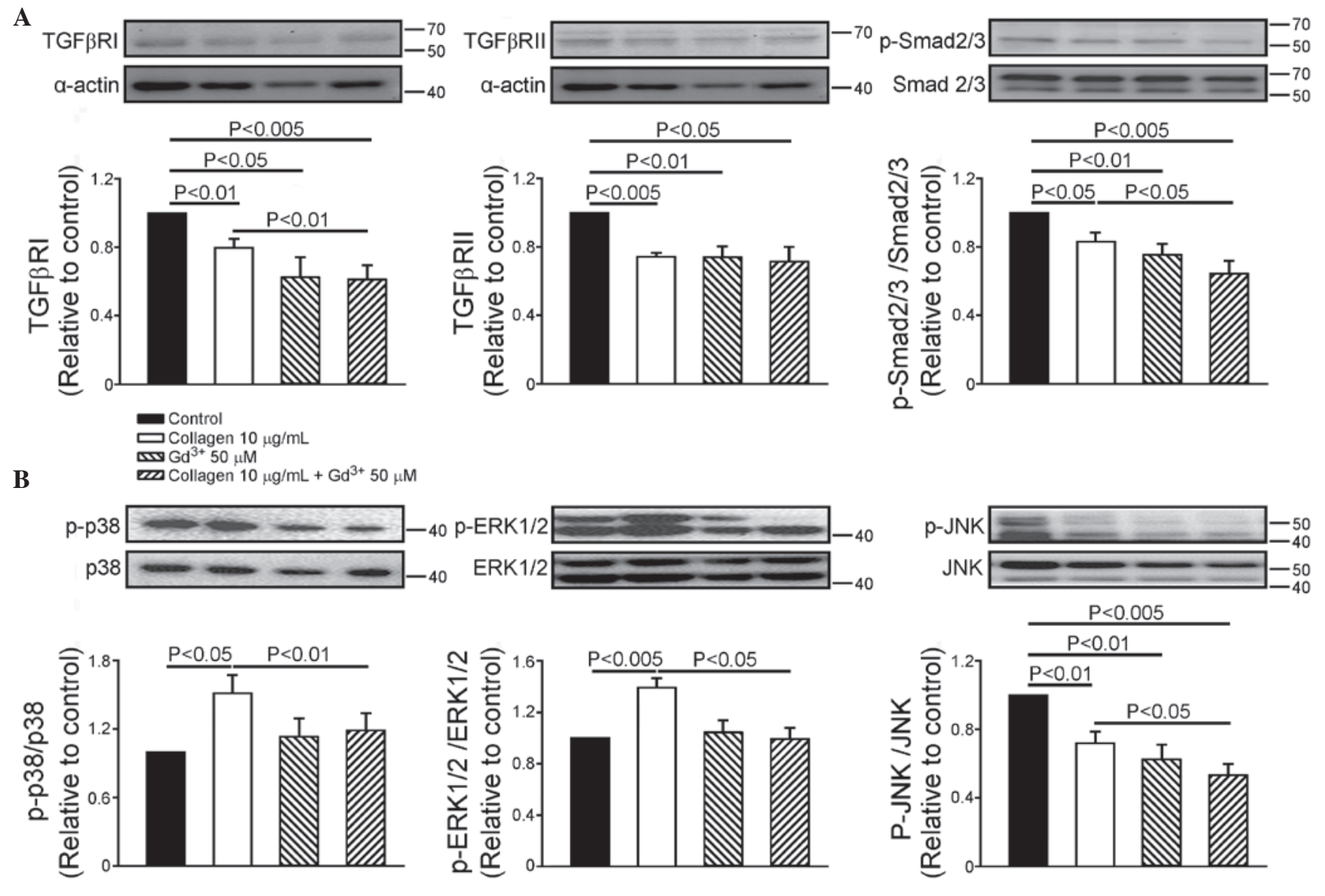

Figure 2. Effects of $\mathrm{Gd}^{3+}$ on TGF $\beta$ RI, TGF $\beta$ RII and Smad2/3, and the phosphorylation of mitogen-activated protein kinases. (A) Representative images and quantified data of TGFßRI, TGF $\beta$ RII and Smad2/3 ( $n=7)$ and (B) phosphorylation ratios of p38, ERK1/2 and JNK (n=6) in the control, collagen $(10 \mu \mathrm{g} / \mathrm{ml})$-treated, $\mathrm{Gd}^{3+}(50 \mu \mathrm{M})$-treated and collagen $(10 \mu \mathrm{g} / \mathrm{ml})$ with $\mathrm{Gd}^{3+}(50 \mu \mathrm{M})$-treated groups. Data are presented as the mean \pm standard error of the mean. $\mathrm{Gd}^{3+}$, gadolinium; TGF $\beta R$, transforming growth factor $\beta$ receptor; ERK1/2, extracellular-regulated kinase 1/2; JNK, Jun N-terminal kinase; Smad, small mothers against decapentaplegic; Ab, antibody; p-, phosphorylated.

of FAK, but did not alter the collagen-associated downregulation of TGF $\beta$ RI.

Effects of collagen and $\beta 1$ integrin in the modulation of $M A P K$ phosphorylation. As shown in Fig. 1B, the collagen (10 $\mu \mathrm{g} / \mathrm{ml})$-treated HL-1 cells exhibited increased phos-

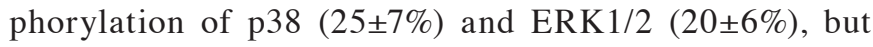
decreased the phosphorylation of JNK $(13 \pm 5 \%)$. The $\beta 1$ integrin antibody increased the phosphorylation of p38 by $55 \pm 15 \%$ in the HL-1 cells, but did not affect the phosphorylation of ERK1/2 or JNK. Therefore, $\beta 1$ integrin was expected to increase the level of phosphorylated p38. In the presence of the $\beta 1$ integrin antibody, collagen did not alter the phosphorylation of $\mathrm{p} 38$, however, the phosphorylation of ERK1/2 was increased and that of JNK was decreased. Accordingly, the collagen-induced changes in the levels of phosphorylated ERK1/2 and JNK were not altered by the presence of the $\beta 1$ integrin antibody, which suggested that integrin may not completely modulate the collagen effects of collagen on MAPKs.

Effect of mechanical stretch in collagen-mediated expression of the TGF- $\beta$ receptor and Smad2/3. Compared with the control, gadolinium $(50 \mu \mathrm{M})$ decreased the expression of TGF $\beta$ RI by $38 \pm 12 \%$ and TGF $\beta$ RII by $26 \pm 6 \%$. In the presence of gadolinium, collagen did not alter the expression levels of TGF $\beta$ RI or TGF $\beta$ RII. However, gadolinium decreased the collagen-induced downregulation of TGF $\beta$ RI by $25 \pm 7 \%$. Collagen decreased the phosphorylation of $\operatorname{Smad} 2 / 3$ by $17 \pm 5 \%$, compared with the control. Gadolinium $(50 \mu \mathrm{M})$ decreased the phosphorylation of Smad2/3 in the HL-1 cells by $24 \pm 6 \%$, and decreased the phosphorylation of $\operatorname{Smad} 2 / 3$ by $23 \pm 6 \%$ in the presence of collagen (Fig. 2A).

Effect of mechanical stretch on the collagen-mediated phosphorylation of MAPKs. Compared with the control cells, the gadolinium (50 $\mu \mathrm{M})$-treated HL-1 cells exhibited decreased JNK phosphorylation by $37 \pm 6 \%$, however, the phosphorylation of p38 or ERK1/2 were not affected. In the presence of gadolinium, collagen did not alter the phosphorylation of p38, ERK or JNK. However, gadolinium further decreased the collagen-induced downregulated phosphorylation of JNK by $25 \pm 8 \%$, and reversed the collagen-induced upregulated phosphorylation of p38 and ERK1/2, compared with the collagen-treated HL-1 cells (Fig. 2B).

Effects of $\beta 1$ integrin and mechanical stretch on the collagen-mediated expression of TGF- $\beta$ receptor and Smad2/3. As shown in Fig. 3A, the $\beta 1$ integrin antibody $(10 \mu \mathrm{g} / \mathrm{ml})$ and gadolinium $(50 \mu \mathrm{M})$ decreased the expres- 
$\mathbf{A}$
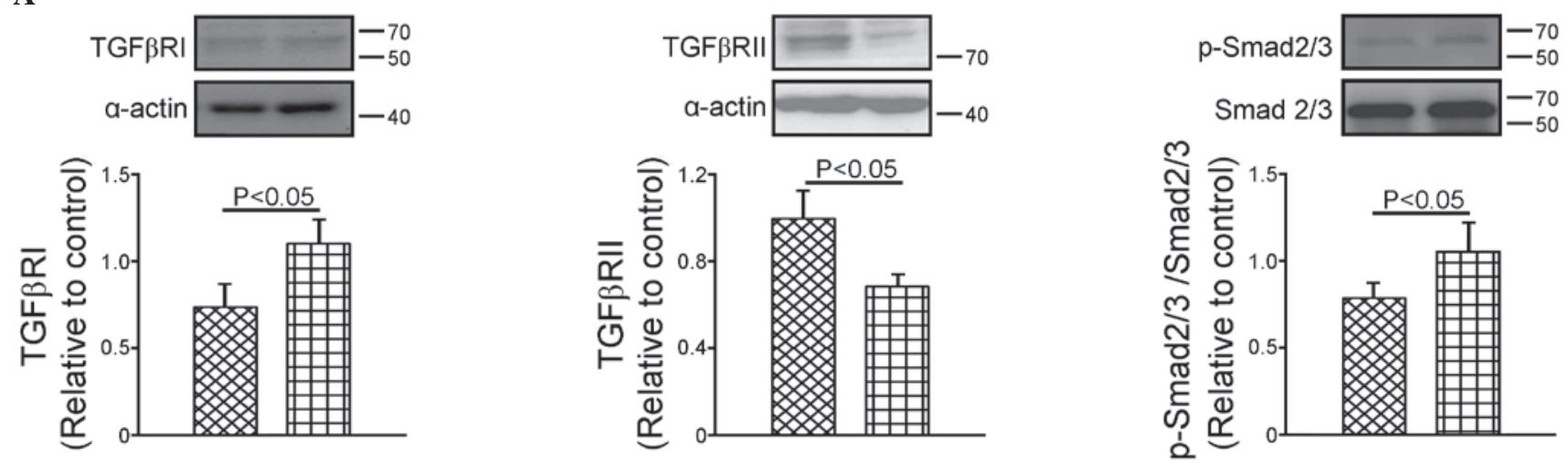

Mollagen $10 \mu \mathrm{g} / \mathrm{mL}+\beta 1$ integrin $A b 10 \mu \mathrm{g} / \mathrm{mL}+\mathrm{Gd}^{3+} 50 \mu \mathrm{M}$ 国 $\beta 1$ integrin $A b 10 \mu \mathrm{g} / \mathrm{mL}+\mathrm{Gd}^{3+} 50 \mu \mathrm{M}$

B
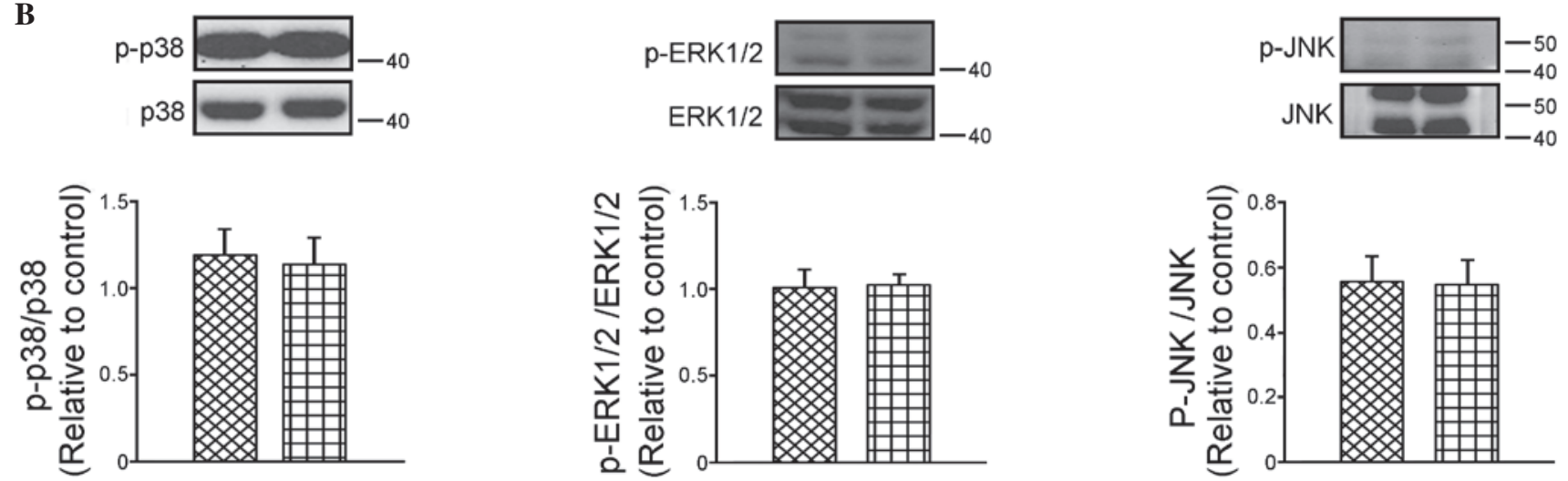

Figure 3. Effects of $\beta 1$ integrin $\mathrm{Ab}$ and $\mathrm{Gd}^{3+}$ on the expression of TGF $\beta$ RI, TGF $\beta$ RII and Smad2/3 and the phosphorylation of mitogen-activated protein kinases. (A) Representative images and quantified data ( $\mathrm{n}=7)$ of TGF $\beta$ RI, TGF $\beta$ RII and Smad2/3 in the groups treated with collagen, $\beta 1 \mathrm{integrin} \mathrm{Ab}(10 \mu \mathrm{g} / \mathrm{ml})$ and $\mathrm{Gd}^{3+}(50 \mu \mathrm{M})$, and with $\beta 1$ integrin $\mathrm{Ab}(10 \mu \mathrm{g} / \mathrm{ml})$ and $\mathrm{Gd}^{3+}(50 \mu \mathrm{M})$. (B) Representative images and quantified data (n=6) of the phosphorylation ratios of p38, ERK1/2 and JNK in the groups treated with the collagen, $\beta 1$ integrin $\mathrm{Ab}(10 \mu \mathrm{g} / \mathrm{ml})$ and $\mathrm{Gd}^{3+}(50 \mu \mathrm{M})$, and with $\beta 1$ integrin $\mathrm{Ab}\left(10 \mu \mathrm{g} / \mathrm{ml}^{2}\right.$ and Gd ${ }^{3+}$ $(50 \mu \mathrm{M})$. Data are presented as the mean \pm standard error of the mean. $\mathrm{Gd}^{3+}$, gadolinium; TGF $\beta$ R, transforming growth factor $\beta$ receptor; FAK, focal adhesion kinase; ERK1/2, extracellular-regulated kinase 1/2; JNK, Jun N-terminal kinase; Ab, antibody; p-, phosphorylated.

sion of TGF $\beta$ RII by $32 \pm 6 \%$ ( $\mathrm{P}<0.05$, vs. control), however, no change in the expression of TGF $\beta$ RI was observed in the HL- 1 cells. In the presence of the $\beta 1$ integrin antibody and gadolinium, collagen downregulated TGF $\beta$ RI by $66 \pm 23 \%$ and upregulated TGF $\beta$ RII by $26 \pm 8 \%$. Compared with the gadolinium-treated cells (Fig. 2A), the HL-1 cells treated with the $\beta 1$ integrin antibody and gadolinium (Fig. 3A) increased the expression of TGF $\beta$ RI by $149 \pm 77 \%(\mathrm{P}<0.05)$, however, the expression of TGF $\beta$ RII was not affected (data not shown). The phosphorylation of Smad2/3 in the cells treated with the $\beta 1$ integrin antibody and gadolinium did not differ from that of the control. The effects of the $\beta 1$ integrin antibody and gadolinium on the phosphorylation of Smad2/3 were similar to those on the expression of TGF $\beta$ RI.

Effects of $\beta 1$ integrin and mechanical stretch in the collagen-mediated expression of MAPKs. Compared with the control HL-1 cells, $\beta 1$ integrin antibody $(10 \mu \mathrm{g} / \mathrm{ml})$ and gadolinium $(50 \mu \mathrm{M})$ decreased the phosphorylation of JNK by $45 \pm 8 \%(\mathrm{P}<0.005)$, but did not alter the phosphorylation of $\mathrm{p} 38$ or ERK1/2 (Fig. 3B). In the presence of $\beta 1$ integrin antibody and gadolinium, no changes in the phosphorylation of p38, ERK1/2 or JNK were observed, compared with the gadolinium-treated cells and the cells concomitantly treated with collagen.

Effects of $\beta 1$ integrin and mechanical stretch on the proliferation and adhesion of collagen-treated HL-1 cells. To investigate the role of integrin and mechanical stretch on cell proliferation, the collagen $(10 \mu \mathrm{g} / \mathrm{ml})$-treated HL-1 cells were incubated with or without $\beta 1$ integrin antibody $(10 \mu \mathrm{g} / \mathrm{ml})$ or gadolinium $(50 \mu \mathrm{M})$. As shown in Fig. 4A, collagen increased cell proliferation, and this collagen-induced cell proliferation was inhibited by $\beta 1$ integrin antibody, but not by gadolinium. In addition, collagen increased cell adhesion by $16 \pm 7 \%$, which was also inhibited by $\beta 1$ integrin antibody (Fig. 4B). These results suggested that collagen promoted cardiomyocyte proliferation and adhesion through $\beta 1$ integrin signaling.

Effect of MAPK inhibition on the proliferation of collagen-treated HL-1 cells. Compared with the control HL-1 cells, SB203580 (3 $\mu \mathrm{M})$ increased cell proliferation by $33 \pm 11 \%$, whereas PD98059 $(50 \mu \mathrm{M})$ and SP600125 $(50 \mu \mathrm{M})$ did not alter cell proliferation (Fig. 5). However, in the presence of collagen, PD98059 and SP600125, but not SB203580, inhibited the collagen-induced increase in cell proliferation. 

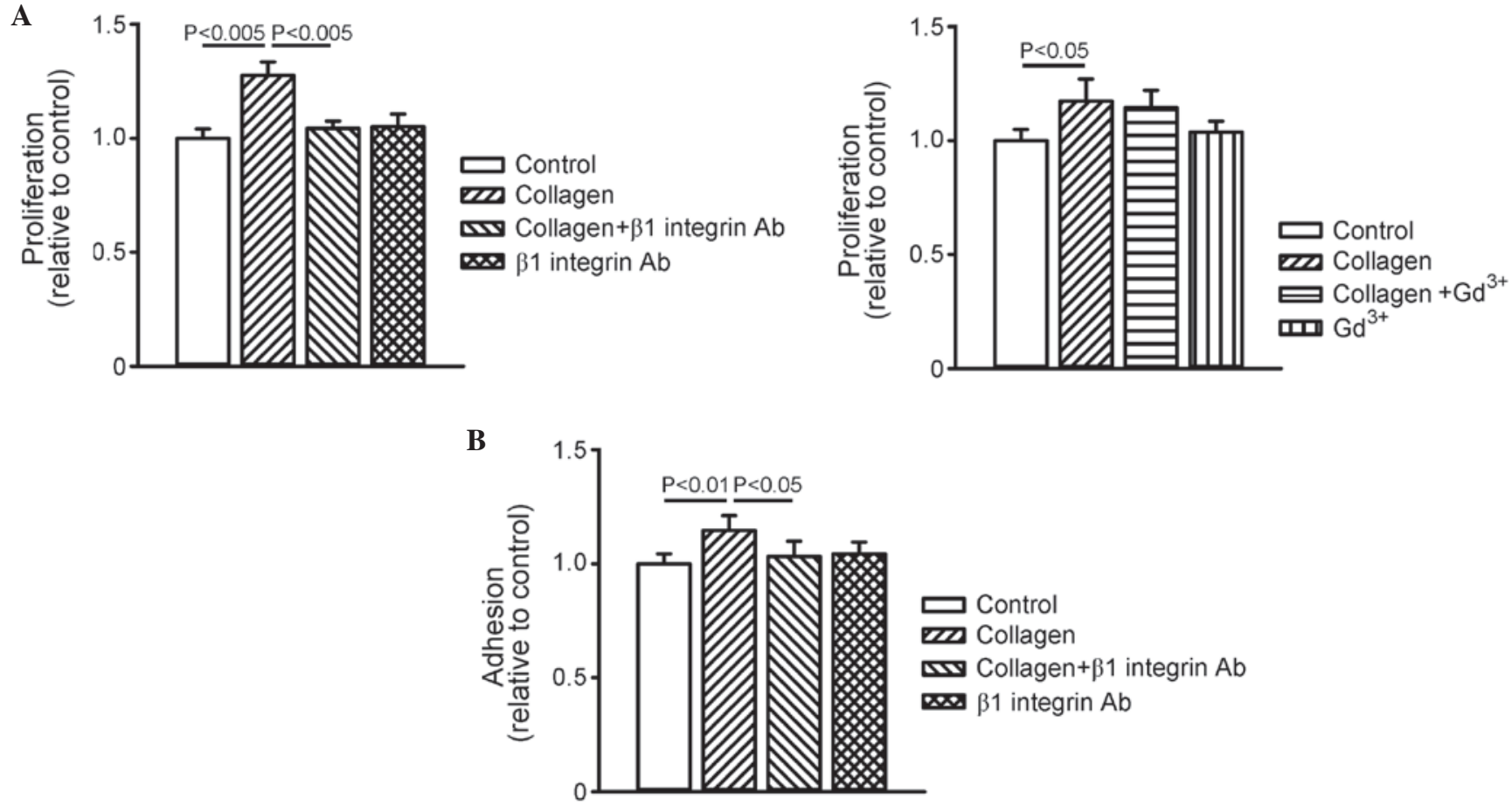

Figure 4. Effects of collagen, $\beta 1$ integrin $\mathrm{Ab}$ and $\mathrm{Gd}^{3+}$ on cell proliferation and adhesion. (A) Cell proliferation was assessed by BrdU absorbance at $450 \mathrm{~nm}$. The graph on the left shows data ( $\mathrm{n}=9)$ of cell proliferation in the control, collagen $(10 \mu \mathrm{g} / \mathrm{ml})$-treated, collagen $(10 \mu \mathrm{g} / \mathrm{ml})$ with $\beta 1 \mathrm{integrin} \mathrm{Ab}(10 \mu \mathrm{g} / \mathrm{ml})$-treated, and $\beta 1$ integrin $\mathrm{Ab}(10 \mu \mathrm{g} / \mathrm{ml})$-treated groups. The graph on the right shows data $(\mathrm{n}=9)$ of cell proliferation in the control, collagen $(10 \mu \mathrm{g} / \mathrm{ml})$-treated, collagen with $\mathrm{Gd}^{3+}(50 \mu \mathrm{M})$-treated, and $\mathrm{Gd}^{3+}(50 \mu \mathrm{M})$-treated groups. (B) Cell adhesion was assessed by crystal violet absorbance at $540 \mathrm{~nm}$ in the control, collagen $(10 \mu \mathrm{g} / \mathrm{ml})$-treated, collagen $(10 \mu \mathrm{g} / \mathrm{ml})$ with $\beta 1$ integrin $\mathrm{Ab}(10 \mu \mathrm{g} / \mathrm{ml})$-treated, and $\beta 1$ integrin $\mathrm{Ab}(10 \mu \mathrm{g} / \mathrm{ml})$-treated groups. Data are presented as the mean \pm standard error of the mean $(n=9)$. $\mathrm{Gd}^{3+}$, gadolinium; TGF $\beta \mathrm{R}$, transforming growth factor $\beta$ receptor; $\mathrm{Ab}$, antibody.

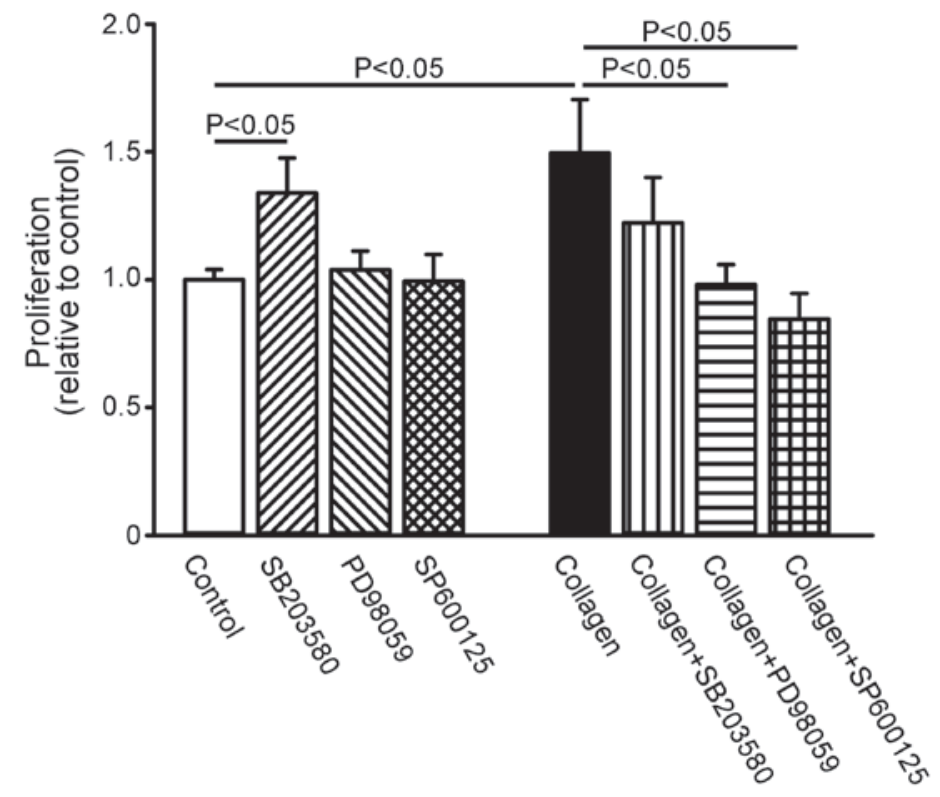

Figure 5. Effects of collagen and mitogen-activated protein kinase inhibitors on cell proliferation. Cell proliferation was assessed by BrdU absorbance at $450 \mathrm{~nm}$. Cell proliferation was determined in the control, collagen $(10 \mu \mathrm{g} / \mathrm{ml})$-treated, SB203580 $(3 \mu \mathrm{M})$-treated, PD98059 (50 $\mu \mathrm{M})$-treated, SP600125 $(50 \mu \mathrm{M})$-treated, collagen $(10 \mu \mathrm{g} / \mathrm{ml})$ with SB203580 $(3 \mu \mathrm{M})$-treated, collagen $(10 \mu \mathrm{g} / \mathrm{ml})$ with PD98059 $(50 \mu \mathrm{M})$-treated, and collagen $(10 \mu \mathrm{g} / \mathrm{ml})$ with $\mathrm{SP} 600125(50 \mu \mathrm{M})$-treated groups. Data are presented as the mean \pm standard error of the mean $(\mathrm{n}=9)$.

\section{Discussion}

The present study is the first, to the best of our knowledge, to demonstrate that collagen directly modulated the expression of TGF- $\beta$ receptors and their downstream signaling molecules.
TGF- $\beta$ is an important cytokine in the fibrotic responses of several organs, including the heart $(6,7)$. The present study demonstrated that collagen accumulation during fibrosis can downregulate the expression of TGF- $\beta$ receptors. TGF- $\beta$ enhances the production of the ECM from cardiac fibroblasts, 
which can induce fibrosis $(6,32)$. Although the underlying mechanisms remain to be fully elucidated, sustained TGF- $\beta$ exposure has been shown to suppress the expression of TGF- $\beta$ receptors (33). Therefore, an increase or decrease of collagen leads to the downregulation or upregulation of TGF- $\beta$ receptor signaling, which may, at least in part, result in the known feedback loop between TGF- $\beta$ and TGF- $\beta$ receptors. In addition, the ECM has been reported to modulate MAPKs in cell function and differentiation $(28,34,35)$. Collagen was found to increase the phosphorylation of p38 and ERK1/2 in the present study, which is compatible with previous findings in cardiac remodeling $(36,37)$.

The present study found that the collagen-induced downregulation of TGF $\beta$ RII was inhibited by the integrin antibody. A previous study demonstrated that the interaction of type I collagen with $\alpha 2 \beta 1$ integrin causes downregulation of the TGF- $\beta$ receptor via the activation of FAK and its diverse downstream signals, and this was found to be abrogated by treatment that inactivated FAK (35). The integrin antibody decreased the collagen-activated phosphorylation of FAK, suggesting that FAK uniquely mediates matrix-integrin interactions in cellular processes. However, integrin did not regulate the effects of collagen on TGF $\beta R I$, suggesting that collagen differentially modulates the expression of TGF $\beta$ RI and TGF $\beta R I I$.

The ECM has a regulatory role in several cellular processes, including cell growth, adhesion, division and differentiation. However, whether collagen regulates cardiomyocyte proliferation and adhesion remains to be elucidated. The ECM secreted from cardiac fibroblasts has been reported to promote cardiomyocyte proliferation through $\beta 1$ integrin signaling (38). Integrins are a major class of ECM receptors for cell adhesion (20). The present study showed that collagen-binding $\beta 1$ integrin is involved in mediating cell proliferation and adhesion, which suggested that $\beta 1$ integrin may be responsible for cardiomyocyte proliferation during cardiac fibrosis. Although the inhibition of p38 enables the proliferation of cardiomyocytes (39), however, collagen-induced cell proliferation was inhibited by the inhibition of ERK in the present study. These results suggested that integrin and MAPK signaling in the cardiomyocytes may have been responsible for the effects of collagen on cardiomyocyte proliferation.

Mechanical stretch induces the release of TGF- $\beta$ and is coupled with intracellular signals, which are responsible for cardiac hypertrophy $(40,41)$. In the present study, it was found that gadolinium enhanced the downregulation of the TGF $\beta$ RI, but not TGF $\beta$ RII. The activation of TGF $\beta$ RI leads to the phosphorylation of Smad2 and Smad3, and regulates transcription $(13,14)$. In the present study, collagen downregulated the phosphorylation of $\mathrm{Smad} 2 / 3$ in parallel with the expression of TGF $\beta$ RI, which suggested that collagen was involved in the Smad-dependent pathway through TGF $\beta$ RI. The MAPK pathway may be involved in the mechanical stretching-induced hypertrophic response $(42,43)$. In the present study, it was found that gadolinium decreased the collagen-induced phosphorylation of p38 and ERK1/2. As gadolinium only reversed the effects of collagen on the activity of MAPKs in cells without the presence of the $\beta 1$-integrin antibody, it is possible that collagen activated the stretch-induced MAPK signaling pathway independently of integrin-FAK signaling (44). However, collagen and gadolinium showed synergistic effects in inhibiting the expression of TGF $\beta$ RI and phosphorylation of Smad2/3. These results suggested the presence of cross-talk between collagen and mechanical stretch in the TGF $\beta$ RI/Smad signaling pathways. The present study demonstrated that collagen regulated the expression of TGF- $\beta$ receptors and phosphorylation of MAPKs through at least two distinct mechanisms. Collagen regulated the expression of TGF $\beta$ RII through cross-talk between integrin-FAK signaling and mechanical stretch, whereas the collagen-induced expression of TGF $\beta$ RI and activation of MAPKs were predominantly mediated by mechanical stretch. In addition, collagen may modulate the phosphorylation of JNK beyond the mechanisms identified in the present study. In the present in vitro study, an atrial cell line from mice was used, and these highly purified cells were placed on an artificial collagen matrix, which may or may not be reflective of human atrial cells. The findings suggested that coordinated actions occurred among the ECM, integrin and mechanical stretch in response to cardiac fibrosis.

In conclusion, the present study demonstrated that collagen was involved in altering intracellular signaling in a positive and negative manner. The observations indicated that collagen modulated the expression of TGF- $\beta$ receptors and the phosphorylation of MAPKs through interactions with integrin and mechanical stretch.

\section{Acknowledgements}

This study was supported by grants (grant nos. NSC1012314-B-040-017-MY2, NSC102-2314-B-016-029-MY2, NSC102-2325-B-010-005, NSC102-2628-B-038-002-MY3 and 103-2314-B-281-005-MY2) from the National Science Council of Taiwan (grant nos. 102CGH-TMU-04, CGH-MR-A10219, CGH-MR-A10221, CGH-MR-A10222, CGH-MR-A10305 and 105CGH-TMU-08) from Cathay General Hospital (Taipei, Taiwan) and (grant nos. 103swf05, 103-wf-eva-02, 104-wf-eva-01, 104swf02, and 105-wf-eva-14) from Wan Fang Hospital, Taipei Medical University (Taipei, Taiwan).

\section{References}

1. Sugden PH and Clerk A: Cellular mechanisms of cardiac hypertrophy. J Mol Med (Berl) 76: 725-746, 1998.

2. Manabe I, Shindo T and Nagai R: Gene expression in fibroblasts and fibrosis: Involvement in cardiac hypertrophy. Circ Res 91: 1103-1113, 2002.

3. Swynghedauw B: Molecular mechanisms of myocardial remodeling. Physiol Rev 79: 215-262, 1999.

4. Bissell MJ, Hall HG and Parry G: How does the extracellular matrix direct gene expression? J Theor Biol 99: 31-68, 1982.

5. Pelouch V, Dixon IM, Golfman L, Beamish RE and Dhalla NS: Role of extracellular matrix proteins in heart function. Mol Cell Biochem 129: 101-120, 1993.

6. Border WA and Noble NA: Transforming growth factor beta in tissue fibrosis. N Engl J Med 331: 1286-1292, 1994.

7. Lijnen PJ, Petrov VV and Fagard RH: Induction of cardiac fibrosis by transforming growth factor-beta (1). Mol Genet Metab 71: 418-435, 2000.

8. Hein S, Arnon E, Kostin S, Schönburg M, Elsässer A, Polyakova V, Bauer EP, Klövekorn WP and Schaper J: Progression from compensated hypertrophy to failure in the pressure-overloaded human heart: Structural deterioration and compensatory mechanisms. Circulation 107: 984-991, 2003. 
9. Nakajima H, Nakajima HO, Salcher O, Dittiè AS, Dembowsky K, Jing S and Field LJ: Atrial but not ventricular fibrosis in mice expressing a mutant transforming growth factor-beta (1) transgene in the heart. Circ Res 86: 571-579, 2000.

10. Shi Y and Massagué J: Mechanisms of TGF-beta signaling from cell membrane to the nucleus. Cell 113: 685-700, 2003.

11. Wrana JL, Attisano L, Cárcamo J, Zentella A, Doody J, Laiho M, Wang XF and Massague J: TGF beta signals through a heteromeric protein kinase receptor complex. Cell 71: 1003-1014, 1992.

12. Chen R, Halder G, Zhang Z and Mardon G: Signaling by the TGF-beta homolog decapentaplegic functions reiteratively within the network of genes controlling retinal cell fate determination in Drosophila. Development 126: 935-943, 1999.

13. Derynck R and Zhang YE: Smad-dependent and Smad-independent pathways in TGF-beta family signalling. Nature 425: 577-584, 2003.

14. Dennler S, Itoh S, Vivien D, ten Dijke P, Huet S and Gauthier JM: Direct binding of Smad3 and Smad4 to critical TGF beta-inducible elements in the promoter of human plasminogen activator inhibitor-type 1 gene. EMBO J 17: 3091-3100, 1998.

15. Bujak M and Frangogiannis NG: The role of TGF-beta signaling in myocardial infarction and cardiac remodeling. Cardiovasc Res 74: 184-195, 2007.

16. Ross RS and Borg TK: Integrins and the myocardium. Circ Res 88: 1112-1119, 2001.

17. McNicholas-Bevensee CM, DeAndrade KB, Bradley WE, Dell'Italia LJ, Lucchesi PA and Bevensee MO: Activation of gadolinium-sensitive ion channels in cardiomyocytes in early adaptive stages of volume overload-induced heart failure. Cardiovasc Res 72: 262-270, 2006.

18. Clark EA and Brugge JS: Integrins and signal transduction pathways: The road taken. Science 268: 233-239, 1995.

19. Schlaepfer DD, Hanks SK, Hunter T and van der Geer P: Integrin-mediated signal transduction linked to Ras pathway by GRB2 binding to focal adhesion kinase. Nature 372: 786-791, 1994.

20. Hynes RO: Integrins: Bidirectional, allosteric signaling machines. Cell 110: 673-687, 2002.

21. Margadant $C$ and Sonnenberg A: Integrin-TGF-beta crosstalk in fibrosis, cancer and wound healing. EMBO Rep 11: 97-105, 2010.

22. Parsons JT, Schaller MD, Hildebrand J, Leu TH, Richardson A and Otey C: Focal adhesion kinase: Structure and signalling. J Cell Sci Suppl 18: 109-113, 1994

23. Aikawa R, Nagai T, Kudoh S, Zou Y, Tanaka M, Tamura M, Akazawa H, Takano H, Nagai R and Komuro I: Integrins play a critical role in mechanical stress-induced p38 MAPK activation. Hypertension 39: 233-238, 2002.

24. Komuro I, Kudo S, Yamazaki T, Zou Y, Shiojima I and Yazaki Y: Mechanical stretch activates the stress-activated protein kinases in cardiac myocytes. FASEB J 10: 631-636, 1996.

25. Blaauw E, van Nieuwenhoven FA, Willemsen P, Delhaas T, Prinzen FW, Snoeckx LH, van Bilsen M and van der Vusse GJ: Stretch-induced hypertrophy of isolated adult rabbit cardiomyocytes. Am J Physiol Heart Circ Physiol 299: H780-H787, 2010.

26. Asrih M, Mach F, Nencioni A, Dallegri F, Quercioli A and Montecucco F: Role of mitogen-activated protein kinase pathways in multifactorial adverse cardiac remodeling associated with metabolic syndrome. Mediators Inflamm 2013: 367245, 2013.

27. Lu YY, Chen YC, Kao YH, Wu TJ, Chen SA and Chen YJ: Extracellular matrix of collagen modulates intracellular calcium handling and electrophysiological characteristics of HL-1 cardiomyocytes with activation of angiotensin II type 1 receptor. J Card Fail 17: 82-90 2011

28. Lu YY, Chen YC, Kao YH, Chen SA and Chen YJ: Extracellular matrix of collagen modulates arrhythmogenic activity of pulmonary veins through p38 MAPK activation. J Mol Cell Cardiol 59: 159-166, 2013.
29. Claycomb WC, Lanson NA Jr, Stallworth BS, Egeland DB, Delcarpio JB, Bahinski A and Izzo NJ Jr: HL-1 cells: A cardiac muscle cell line that contracts and retains phenotypic characteristics of the adult cardiomyocyte. Proc Natl Acad Sci USA 95: 2979-2984, 1998.

30. Hou G, Mulholland D, Gronska MA and Bendeck MP: Type VIII collagen stimulates smooth muscle cell migration and matrix metalloproteinase synthesis after arterial injury. Am J Pathol 156: 467-476. 2000.

31. Pascarel C, Hongo K, Cazorla O, White E and Le Guennec JY Different effects of gadolinium on I (KR), I (KS) and I (K1) in guinea-pig isolated ventricular myocytes. Br J Pharmacol 124: 356-360, 1998

32. Eghbali M, Tomek R, Sukhatme VP, Woods C and Bhambi B: Differential effects of transforming growth factor-beta 1 and phorbol myristate acetate on cardiac fibroblasts. Regulation of fibrillar collagen mRNAs and expression of early transcription factors. Circ Res 69: 483-490. 1991.

33. Kim KK, Ji C, Chang W, Wells RG, Gundberg CM, McCarthy TL and Centrella M: Repetitive exposure to TGF-beta suppresses TGF-beta type I receptor expression by differentiated osteoblasts. Gene 379: 175-184, 2006.

34. Morino N, Mimura T, Hamasaki K, Tobe K, Ueki K, Kikuchi K, Takehara K, Kadowaki T, Yazaki Y and Nojima Y: Matrix/integrin interaction activates the mitogen-activated protein kinase, p44erk-1 and p42erk-2. J Biol Chem 270: 269-273, 1995.

35. Takeuchi Y, Suzawa M, Kikuchi T, Nishida E, Fujita T and Matsumoto T: Differentiation and transforming growth factor-beta receptor down-regulation by collagen-alpha2beta 1 integrin interaction is mediated by focal adhesion kinase and its downstream signals in murine osteoblastic cells. J Biol Chem 272: 29309-29316, 1997.

36. Sadoshima J and Izumo S: Mechanical stretch rapidly activates multiple signal transduction pathways in cardiac myocytes: Potential involvement of an autocrine/paracrine mechanism. EMBO J 12: 1681-1692, 1993

37. Kudoh S, Komuro I, Hiroi Y, Zou Y, Harada K, Sugaya T, Takekoshi N, Murakami K, Kadowaki T and Yazaki Y: Mechanical stretch induces hypertrophic responses in cardiac myocytes of angiotensin II type 1a receptor knockout mice. J Biol Chem 273: 24037-24043, 1998.

38. Ieda M, Tsuchihashi T, Ivey KN, Ross RS, Hong TT, Shaw RM and Srivastava D: Cardiac fibroblasts regulate myocardial proliferation through beta1 integrin signaling. Dev Cell 16: 233-244, 2009.

39. Engel FB, Schebesta M, Duong MT, Lu G, Ren S, Madwed JB, Jiang H, Wang Y and Keating MT: p38 MAP kinase inhibition enables proliferation of adult mammalian cardiomyocytes. Genes Dev 19: 1175-1187, 2005.

40. Sadoshima J, Jahn L, Takahashi T, Kulik TJ and Izumo S: Molecular characterization of the stretch-induced adaptation of cultured cardiac cells. An in vitro model of load-induced cardiac hypertrophy. J Biol Chem 267: 10551-11560, 1992.

41. Takahashi N, Calderone A, Izzo NJ Jr, Mäki TM, Marsh JD and Colucci WS: Hypertrophic stimuli induce transforming growth factor-beta 1 expression in rat ventricular myocytes. J Clin Invest 94: 1470-1476, 1994.

42. Wang Y, Huang S, Sah VP, Ross J Jr, Brown JH, Han J and Chien KR: Cardiac muscle cell hypertrophy and apoptosis induced by distinct members of the p38 mitogen-activated protein kinase family. J Biol Chem 273: 2161-2168, 1998.

43. Seko Y, Takahashi N, Tobe K, Kadowaki T and Yazaki Y: Pulsatile stretch activates mitogen-activated protein kinase (MAPK) family members and focal adhesion kinase (p125 (FAK)) in cultured rat cardiac myocytes. Biochem Biophys Res Commun 259: 8-14, 1999.

44. Hsu HJ, Lee CF, Locke A, Vanderzyl SQ and Kaunas R: Stretch-induced stress fiber remodeling and the activations of JNK and ERK depend on mechanical strain rate, but not FAK. PLoS One 5: e12470, 2010. 